\title{
Skandinavisk sci-fi-poesi
}

\section{Med særligt henblik på aktuel cli-fi-poesi}

Man kan forestille sig meget. Også at der stadigvæk er nogen, som ikke ved, at der findes science fiction-poesi (sci-fi-poesi). Men det gør der. Science fiction (sci-fi) er ikke blot en genremærkat, man sætter på bestemte former for film, tv-serier og romaner. De karakteristika, man forbinder med sci-fi, har man i stigende grad set poesien benytte sig af. Selvom sci-fi er kendetegnet ved at fremstille potentielle scenarier, er fænomenet sci-fi-poesi således selv langt fra en luftig forestilling. Det er derimod en levende realitet, og i de seneste år har denne form for poesi endda bredt sig i en sådan grad, at den er kommet til at udgøre en markant understrøm i skandinavisk digtning. Stadigt flere af de yngre, toneangivende lyrikere har taget genren til sig og opsøgt de muligheder, den indebærer. Det viser sig såvel i værker, der i deres helhed kan betegnes sci-fi-poesi, som i digtsamlinger, der i større eller mindre omfang anvender motiver og greb med tilknytning til genren. ${ }^{\mathrm{I}}$

Imidlertid er feltet for sci-fi-poesi endnu ikke særligt velbeskrevet, og i denne artikel vil jeg derfor først introducere til sci-fi og sci-fi-poesi mere generelt, hvorefter jeg vil komme ind på det, der er artiklens hovedemne, nemlig aktuel skandinavisk sci-fi-poesi. Her vil jeg især se på den del af denne, som forholder sig til klimakrisen og de mulige katastrofescenarier, den stiller os over for, og som man også kan benævne cli-fi-poesi. Min grundantagelse er, at væksten inden for den poetiske sci-fi i Skandinavien skyldes, at der er fremkommet en politisk engageret generation af lyrikere, som er optaget af de presserende problematikker, der præger samtiden og herunder ikke mindst rejses med reference til Antropocæn og klimakrise. Digtere, som oplever at leve i en truet verden og føler et akut behov for og en skærpet forpligtelse til med sprogligt æstetiske virkemidler at italesætte de alvorlige problemer og opsøge de fremtidsscenarier, vores aktuelle levevis risikerer at medføre. Som vi skal se, giver sci-fi en oplagt ramme herfor. 


\section{Sci-fi og sci-fi-poesi i et litteraturhistorisk perspektiv}

Sci-fi er en genre, hvis litterære lødighed længe var omdiskuteret, men som i dag har vundet bred anerkendelse for sine kunstnerisk interessante og intellektuelt udfordrende potentialer. Mens den tidlige sci-fi ofte udkom i magasiner og blev forbundet med kiosk- og genrelitteratur af en til tider tvivlsom æstetisk kvalitet, har man fra 1960'erne og frem oplevet, at skellet mellem fin- og populærkultur er blevet stadigt mere nedbrudt, ligesom en lang række velrenommerede forfattere har udfoldet sig inden for genren. Til trods for at sci-fi er blevet tildelt større bevågenhed, er forestillingen om den miskrediterede genre imidlertid endnu ikke helt forladt. Eksempelvis indleder Niels Dalgaard sin bog Vinkler på dansk science fiction (2015) med ordene: "Science fiction-litteratur for voksne er stort set usynlig herhjemme. Den danske litteraturhistorieskrivning ignorerer eller foragter genren i en sådan grad, at den normalt skrives helt ud af historien" (Dalgaard, 7). Om det reelt forholder sig så galt, kan dog diskuteres. I hvert fald er det voldsomme ord taget i betragtning, at denne del af litteraturen har oplevet en markant fremgang især igennem det seneste årti og her er repræsenteret ved anerkendte og velomtalte danske forfattere som fx Svend Åge Madsen, Charlotte Weitze, Kim Leine, Pablo Henrik Llambías, Ursula Scavenius, Kasper Colling Nielsen, Maria Gerhardt, Lars Skinnebach, Theis Ørntoft, Ursula Andkjær Olsen, Olga Ravn, Lea Marie Løppenthin, Peter Adolphsen, Caspar Eric, Jonas Eika og Dennis Gade Kofoed. ${ }^{2}$

Som denne række af navne viser, er det endvidere ikke kun inden for prosaens - for ikke at sige filmens og seriens - rammer, at sci-fi sætter sig igennem. Poesien har tilsvarende fulgt trop. På et internationalt plan blev et vigtigt skridt i synliggørelsen af den poetiske underafdeling af sci-fi taget i 1978 med etableringen af The Science Fiction Poetry Association, der i 2017 blev omdøbt til The Science Fiction \& Fantasy Poetry Association. Bag dannelsen af denne organisation lå et ønske om at skabe et mødested for poeter og læsere med interesse i spekulativ poesi, og scifi-poesi synes generelt at have stået stærkere i USA og England (https://www.sfpoetry.com/). I Skandinavien forblev genren derimod længe upåagtet. Mens der nok havde været forskellige initiativer, der eksponerede prosaformerne inden for sci-fi - hos Dalgaard kan man bl.a. læse om skiftende danske sci-fi-serier og -magasiner fra slut halvtresserne og frem, ligesom den danske forening Science Fiction Cirklen har eksisteret siden $1974^{3}$ - fattedes der en tilsvarende lyrisk platform, og i lang tid viste sci-fi-poesien sig da også alene i form af enkeltstående værker som Finn Bjørnseth: Til minne om en klode (1955), Harry Martinson: Aniara (1956), Klaus Høeck: Projekt Perseus (1977) og Michael Strunge: Fremtidsminder (1980). Af disse var det endvidere kun Martinsons langdigt, der blev en læsersucces og nåede ud til et bredere publikum. ${ }^{4}$

Selvom den skandinaviske gren af sci-fi-poesien ikke har hverken stærke eller vidtforgrenede rødder, er det dog lykkedes for den at skyde betragteligt i vejret på det seneste. På denne side af årtusindeskiftet er der blevet udgivet en flerhed af værker, man enten i sin helhed kan betegne sci-fi-poesi, eller som indeholder elementer af sci-fi og aktiverer nogle af genrens træk. Det drejer sig fx om Eli I. Lund: Jeg vil have sex med en kvinde fra fremtiden (2002), Øyvind Rimbereid: Solaris korrigert (2004), Johannes Heldéns samlede produktion fra Burner i 2003 til First Contact i 
2019, Marianne Larsen: Stjerne for en frafalden (2006) og Sviml ud (2018), Kristofer Flensmarck: Den sista expeditionen (2007), Viktor Johansson: Eterneller (2008), Terje Dragseth: Bella Blu (2011), Glenn Christian: Mudret sol (2013) og Månen atlas over sandparken avenue (2018), Lina Österman: Flodsökare (2014), Ursula Andkjær Olsen: Udgående fartøj (2015), Maria Dorothea Schrattenholz: Atlaspunkt (2015), Theis Ørntoft: Digte 2014 (2014), Caspar Eric: 7/11 (2014), Nike (2015) og Avatar (2017), Liv Sejrbo Lidegaard: Fælleden (2015) samt Lars Skinnebach: Øvelser og rituelle tekster (2011) og Teotwawki (2018). Hertil kommer, at genren udfolder sig inden for diverse litterære fora på internettet og på nogle af de mange poetiske scener, man har set skyde op i det nye årtusinde, og som muliggør, at poesi, der ikke er tilgængelig i trykte digtsamlinger, også kan komme til orde.

Denne vækst synes at stå i nær forbindelse med, hvad sci-fi er for en størrelse, og hvad genren kan og gør. Som man kan læse i David Seeds introduktion til A Companion to Science Fiction (2005), indeholder sci-fi en spænding mellem to begreber, hvor det første associerer til faktuel, velstruktureret viden og det andet til imaginære konstruktioner (Seed, 4f.). Sci-fi læner sig op ad en videnskabelig diskurs og trækker på nye teknologiske landvindinger, samtidig med at genren fremmedgør sin læser fra dennes genkendelige verden. Som sådan leger sci-fi med vores forestilling om virkeligheden og ansporer til refleksion over fremtiden. Som al anden fiktion skaber sci-fi alternative verdener, men derudover appellerer den ifølge Seed også til, at læseren overvejer disse verdeners plausibilitet: "In that sense reading SF is a comparative exercise where we cross-relate the familiar to the strangely new" (ibid.).

Når sci-fi fremstiller et hypotetisk scenarium, er det derfor ikke mindst med sigte på at udforske spændinger og problematikker i det eksisterende samfund og lægge op til nye perspektiver på virkeligheden. Eller som Morten Auklend formulerer det i afhandlingen "EIN systm total"? Utopier og dystopier i norsk etterkrigslitteratur (2010), er sci-fi en måde at foregribe og forestille sig det, som endnu ikke eksisterer. Auklend skriver, at genren "ekstrapolerer forfatterens samfunn og blir et 'narrespeil' som leseren kan se seg selv og sin tid i. Underliggjøringen av det kjente og dislokringen av leseren er sjangerens sentrale grep" (Auklend, 10). Det kan også ses i sammenhæng med, at flere betoner, at det centrale ved sci-fi angår de spørgsmål, den rejser, mere end de svar, den giver. Som Søren Baggesen fremhæver i bogen Natur/videnskab/ fortælling. Om science fiction som civilisationskritik (1993) "bliver det mindre interessant at spørge om hvad den [science fiction] er, det er spørgsmålet om hvad den kan, der er interessant" (Baggesen, 27).

Endvidere er det vigtigt at understrege, at sci-fi ikke kun indholdsmæssigt optegner alternativer til det eksisterende, men at genren også ofte er formsprogligt nyskabende. Nok er der ræson i at fremhæve sci-fi som en primært tematisk orienteret genrebetegnelse, der - med Darko Suvins begreb fra Metamorphoses of Science Fiction: On the Politics and History of a Literary Genre (1979) - indeholder et kognitivt novum, men især hvad angår dens poetiske udtryksformer, er genren kendetegnet ved en æstetisk eksperimenterende karakter. Måske endda ligefrem ved et æstetisk novum. Disse eksperimenter kan finde sted på flere forskellige niveauer. Fx kan det dreje sig om, at sci-fi-poesi transcenderer populær- og finkulturelle strategier samt blander forskellige genrer og tekstformer. Det kan handle om, at sci-fi-poesi benytter sig af 
interartielle og tværmediale udtryksformer og herunder i selve sin form manifesterer sig som en overskridende og teknisk avanceret genre. Og ikke mindst kan de eksperimentelle træk sætte sig igennem i sprogbrugen, hvor der fx optræder nye sproglige udtryk og anvendes multilingvistiske strategier, som konvergerer med øget globalisering og forestillinger om fremtidige sociale strukturer.

I essayet "Dialogues by Starlight. Three Approaches to Writing SF Poetry" forholder Michael Collings sig til genrens eksperimentelle drive, idet han skriver, at sci-fi-poesi

46 works away from traditional forms, language, and/or content, to assert the genre's 'alienness,' its other-ness within the community of poets. Poets exploring this dimension of SF poetry concentrate on the uniqueness of the SF vision and the parallel uniqueness of the language capable of communicating that vision. (Collings 1989)

Med andre ord er der ofte et parløb mellem genrens indholdsmæssigt og formelt nyskabende ambitioner, hvilket er med til at styrke sci-fi-poesiens æstetiske, oplevelses- og erkendelsesmæssige potentiale. Som vi skal se, fremstår skandinavisk scifi-poesi som alt andet end trivial mainstreamlitteratur. Der er tværtimod tale om en i høj grad innovativ og eksperimenterende digtning.

\section{Sci-fi, Antropocæn og klimakrise}

Som allerede antydet synes det ikke mindst at være det visionært kritiske potentiale i sci-fi, der appellerer til samtidens engagerede digtere. Sci-fi tilbyder en ramme for refleksion over og diskussion af mulige konsekvenser af aktuelle problematikker af fx social, politisk og miljømæssig karakter, og derfor forekommer genren særdeles oplagt i den aktuelle situation, hvor den teknologiske udvikling afgørende har ændret de måder, vi kommunikerer og lever på, og hvor avanceret genteknologi, medicinske fremskridt, øget levetid og menneske-maskine-interaktioner radikalt har rokket ved vores opfattelse af, hvad det vil sige at være menneske. For ikke at sige, at sci-fi fremstår som en central udtryksform i en tid, hvor vi er blevet stadigt mere bevidste om og skræmte af den indflydelse, vores menneskelige ageren har på vores omgivelser. Ikke blot det posthumane paradigme og problematikker vedrørende krig, flygtningestrømme, social og politisk ulighed, men særligt klimakrisen og det antropocænes nedbrydning af distinktionen mellem natur og kultur har skabt et forøget behov for refleksion over forholdet mellem vores fortidige, aktuelle og fremtidige levemåde og for, at vi overvejer de konsekvenser, vores ageren risikerer at få.

I flere af de diskussioner, der har været om relationen mellem Antropocæn og litteratur, er det blevet hævdet, at sci-fi er velegnet til netop dette formål. Eksempelvis har Donna Haraway i sin beskrivelse af den nuværende tidsalder ofte refereret til sci-fi og herunder nævnt Ursula K. Le Guin som en primær inspirationskilde. Samtidig henviser begrebet Chthulucene, som hun har lanceret som alternativ til Antropocæn, til sci-fi-forfatteren H. P. Lovecrafts Cthulu-figur, der er et guddommeligt blandingsvæsen og afkom af rumvæsner. Sammen med andre figurer af både klassisk afstamning som Medusa og nyere oprindelse som Ood i sci-fi-serien Doctor Who peger Cht- 
hulu på, at sammenviklinger mellem det menneskelige og ikke-menneskelige er et afgørende kendetegn ved den aktuelle epoke (Haraway). I sci-fi ser man ofte, at mytologiske figurer og spritnye fremtidsvæsner danner parløb, og selvom sådanne skikkelser umiddelbart forekommer fremmede og mærkværdige, kan de i allegorisk form udgøre en ledetråd for en mere hensigtsmæssig måde at betragte verden på.

En anden forsker, som har påpeget relevansen af sci-fi, er Timothy Clark, som skriver, at den primære kunstneriske konsekvens af forsøget på at repræsentere det antropocæne må være en dyb mistro mod enhver traditionel, realistisk æstetik (Clark, 81). I denne forbindelse lyder det om Antropocæn:

6f It may find its analogue in modes of the fantastic, new forms of magic realism or science fiction, or texts in which distinctions between 'character' and 'environment' become fragile or break down, or in which the thoughts and desires of an individual are not intelligible in themselves but only as the epiphenomenal sign of entrapment in some larger and not necessarily benign dynamic. (ibid.)

Haraway og Clark - såvel som en lang række andre aktører inden for feltet - påpeger hermed, at de ændrede vilkår, det antropocæne stiller os overfor, også må føre til en ændring af forfatternes genremæssige og æstetiske strategier. Ligesom der er behov for nye måder at tænke samfundsmæssig og miljømæssig bæredygtig udvikling på, er der brug for andre kunstneriske udtryksformer, der på adækvat vis afspejler vores virkelighed og lægger op til refleksion over, hvilken verden vi ønsker at leve i fremover.

Eller snarere synes det nok at handle om, hvilken fremtid vi skal forsøge at afværge. Der er nemlig en tendens til, at de fremtidsvisioner, der præger både sci-fi generelt og sci-fi-poesi mere specifikt, har fået en markant dystopisk karakter. Balancen mellem de utopiske og dystopiske elementer i sci-fi har forskudt sig, så den dystopiske attitude nu er nærved altdominerende. ${ }^{5}$ I overensstemmelse hermed indleder Morten Auklend sin afhandling med et citat fra den norske avis Klassekampen, som allerede i 2008 skrev: "Dagens framtidsskildrere pensjonerer utopien" (Auklend, 7). Dette synspunkt deler Brian Stableford, og i kapitlet "Science Fiction and Ecology" fra A Companion to Science Fiction (2005) noterer han:

6 With regard to the ecological management of Earth itself, the last quarter of the twentieth century saw a dramatic decline in optimism. Any utopian prospectus for the future, however tentative, had by then to take problems of ecological sustainability into account. (Stableford, 136)

Som denne passage understreger, er det ikke mindst klimakrisen, der har affødt den pessimistiske holdning. Mens mange apokalyptiske fremstillinger fra det 20. århundredes begyndelse skildrede katastrofer forårsaget af udefra kommende forhold, som ikke var under menneskets egen kontrol, er disse katastrofer igennem det 20. århundrede blevet stadigt tættere knyttet til menneskets egen ageren. Hos Stableford lyder det, at omkring det 21. århundrede tager størsteparten af sci-filitteraturen for givet, at den økologiske katastrofe er irreversibel (s. 140). 
Den nære forbindelse mellem sci-fi og klimakrise har ført til udviklingen af genren climate change fiction eller blot cli-fi; en term, der blev lanceret i slutningen af nullerne af Dan Bloom (Flinker, 44). Det er en genre, som forholder sig til de menneskeskabte globale klimaforandringer og livet i en post-apokalyptisk verden. Genren forbinder Antropocæn, klimakrise og sci-fi, og på mange måder fremstår cli-fi som det nye årtusindes primære form for sci-fi. Jens Kramshøj Flinker, der har behandlet den skandinaviske cli-fi i artiklen "Den skandinaviske cli-fi. En ny genre i Antropocæn?" (2018), beskriver genrens funktion på følgende vis: "Clifi'ens styrke er bl.a. at udkaste en verden, som ikke er virkelig, men som kunne være det; den udkaster bl.a. et fiktionsrum, hvori læseren kan indstille sig psykologisk på, hvad det vil sige at leve i en klimaforandret verden" (s. 43). Beskrivelsen ligger snublende nær op ad den måde, sci-fi omtales på, blot med en præcisering af, at cli-fi forholder sig til 'en klimaforandret verden'. Hermed er det forbindelsen til de menneskeskabte, globale klimaforandringer, som udmærker cli-fi frem for andre former for sci-fi og dystopiske fortællinger med fokus på natur- og miljøkatastrofer. Af samme grund taler Flinker i sin beskrivelse af den skandinavisk cli-fi også om en "antropocæn apokalypse" (s. 55) frem for en traditionel dommedagsapokalypse.

Eller rettere gør han det i sin behandling af fem romaner inden for dette felt, for heller ikke i diskussionen af cli-fi har der endnu været nævneværdig opmærksomhed omkring dens lyriske varianter. I sin præsentation af begrebet synes Flinker tværtimod at ekskludere lyrik, idet han alene omtaler cli-fi som en genre, der "omfatter prosafiktioner og film" (s. 41). Til trods for at der igennem de seneste år er kommet betragtelig mere fokus på sci-fi og cli-fi, eksisterer der altså fortsat en vis blindhed over for poesiens potentiale; en blindhed, som muligvis skyldes, at mange forskere inden for feltet tidligere har sat parentes om lyrikkens kompatibilitet med sci-fi under henvisning til, at poesi ikke udgår fra samme virkelighedsbegreb, men essentielt er metaforisk. ${ }^{6}$ At poesien har relevante mellemværender såvel med sci-fi generelt som specifikt med cli-fi, skal vi imidlertid snart få blik for.

\section{Aktuel skandinavisk sci-fi- og cli-fi-poesi}

Blandt den gruppe af digtere, jeg har nævnt som eksponenter for den skandinaviske gren af sci-fi-poesien, skal vi her se nærmere på Lars Skinnebach, Theis Ørntoft, Liv Sejrbo Lidegaard, Caspar Eric, Øyvind Rimbereid, Maria Dorothea Schrattenholz og Johannes Heldén. Det er digtere, der spænder mellem at skrive deciderede scifi-digtsamlinger og mere partielt aktivere nogle af genrens motiviske og udsigelsesmæssige elementer. Når disse forfattere er valgt, skyldes det, at deres brug af sci-fi i udstrakt grad forbinder sig med et antropocænt og også ofte eksplicit klimakritisk perspektiv. På den vis repræsenterer de poesiens deltagelse i den nutidige sci-filitteraturs toneangivende retning, og i flere tilfælde lægger de op til betegnelsen cli-fi-poesi. 


\section{I kredsløb om en dansk planet}

Lars Skinnebach er den danske lyriker, der mest konsekvent har fremhævet klimakrisens overgribende betydning. Det kommer bl.a. til udtryk i Øvelser og rituelle tekster (2011), hvis bagsidetekst bærer overskriften "Kunst der ikke beskæftiger sig med klimakrisen er ikke værd at beskæftige sig med"; et udsagn, som bandet Klimakrisen - som han dannede sammen med Theis Ørntoft - også har brugt som deres motto. I Skinnebachs tematisering af klimaproblematikken er den dystopiske attitude gennemgående. Øvelser og rituelle tekster skriver sig op mod et apokalyptisk fremtidsscenarium og er præget af udsagn som "Vi reagerede ikke hurtigt nok, ikke korrekt på klimakrisen. De politiske systemer, demokratiet i de vestlige lande magtede ikke, de magtede det ikke, at erstatte grundlaget (olieudnyttelsen) for deres egne privilegier" (Skinnebach 2011, 10) og "De demokratiske systemer er allerede brudt sammen, idet de ikke kunne reagere inden for det nødvendige tidsrum, før de katastrofale klimaændringer var irreversible" (s. 59). Cli-fi forstået som etableringen af et fiktionsrum, hvor man kan indstille sig på livet i en klimaforandret verden, er i høj grad en adækvat betegnelse for denne poesi, der også kommer med anvisninger på, hvordan man kan forsøge at forberede sig på de ændrede forhold.

Det er tydeligt fra samlingens første digt, der indledes med ordene "Jeg har de udsendtes / trang til utopier" (s. 9). Digtet aktiverer sci-fi-litteraturens klassiske forestilling om at være udsendt og have behov for at etablere nye lukkede systemer i en ødelagt verden. En verden, hvor sne bliver til "kommende bølger" og "byerne smelter" (ibid.), og som således har referencer til problematikken vedrørende global opvarmning. Men selvom digtet er dystopisk anlagt, har jeget ikke sluppet utopien helt, hvilket man også oplever andre steder i værket, hvor der udtrykkes et håb om, at man i poesien kan etablere et alternativt rum. Samtidig med at der overordnet tales for en mere rituel, praksis- og øvelsesorienteret kunst, der fokuserer på, hvad kunsten gør, frem for hvad den er - hvordan den kan påvirke og initiere forandring - er der altså en modsatrettet drøm om at kunne skabe et eget system; både i skriften og i sin levevis at blive selvforsynende. Desuden befinder værket sig ikke blot tematisk, men også æstetisk i det på én gang åbne og lukkede. Øvelser og rituelle tekster er såvel strukturelt som æstetisk udfordrende og nytænkende. Det viser sig bl.a. i en genremæssig heterogenitet og i en omvending af gængse strukturer, hvor et afsnit med titlen "Forord" er placeret midt i bogen. Værket indfrier Haraways og Clarks fordring om, at der i Antropocæn må nye litterære udtryksformer til.

Det samme gælder Skinnebachs seneste bog TEOTWAWKI (2018), der fremstår som en af de mest radikalt eksperimenterende nye danske digtsamlinger. TEOTWAWKI er akronym for The End Of The World As We Know It, og dommedagsforestillingen trækkes således helt frem i titlen. Udgangspunktet er en radikalt forandret verden, og bogen ligner da heller ikke noget, vi kender fra den samtidige poesi. Snarere er der tale om en poetisk alien, som både i form, layout og indhold er voldsomt eksperimenterende og fremmedartet. Allerede forsiden varsler nye tider. Her optræder et foto med glitch-effekt, der synes at forestille et cylinderformet miniunivers af en slags, ligesom der anvendes skrifttyper, tekstbokse og -bobler, som mimer tegneseriens æstetik. Grænserne mellem fin- og populærkulturen er for længst overskredet, og det er karakteristisk, at digtsamlingen ikke alene er gennemført kal- 
ligraferet og illustreret, men også kommenteret af en anden kunstner. Det drejer sig om dansk-færøske Parl Kristian Bjørn Vester, alias Goodiepal, som højst utraditionelt udtaler sig om Skinnebachs tekster og sideløbende refererer til en lang række andre kunstnere. Værkets koncept afspejler hermed et radikalt opgør med forestillingen om den autonome kunst; med poesi som et selvafgrænset udtryk. I pagt med opfattelsen af Antropocæn som en epoke, hvor gængse grænsedragninger bryder sammen, vises det på værkets æstetisk-formelle niveau, at vante distinktioner falder bort, og et væld af diskurser blander sig med hinanden.

Digtsamlingen består af tre suiter. Den første synes ikke at have en separat titel; de to efterfølgende hedder "Den artificielle have" og "Rent blod", og særligt i den sidste af disse skrues der op for sci-fi-elementerne. Det giver sig udslag i udsagn som "biosfærer på fremmede planeter", "fremtidskroppe", "staten digitaliserer øs børn", "falske signaler til smeltede byer" og " $\varnothing$ føler røde fjer fra fremtiden falde på golde marker, hvor de stiller sig på højkant og sender beskeder til det mulige univers [...] Mennesket lander på et nyt plan og skulle nødigt forstyrre beboerne". Mens $\emptyset$ velser og rituelle tekster nok gestaltede en tydelig klimakritisk diskurs, der forbandt værket med cli-fi, men kun havde få referencer til den klassiske sci-fi's teknisk-videnskabelige diskurser, er disse tydeligt til stede i TEOTWAWKI. Desuden er det foregående værks utopiske indslag trængt i baggrunden. Apokalypsen er en realitet, og værket præsenterer os for et radikalt fremmedartet scenarium, som det er mere end almindeligt svært at få greb om. Den verden, vi føres ind i, er alt andet end genkendelig og betryggende. I stedet fungerer den som et forvrænget spejl, der ansporer læseren til overvejelser over, hvordan det risikerer at gå med os mennesker og den planet, vi har sat så alvorligt under pres.

En anden dansk digter, der kombinerer sci-fi og klimakritiske pointer i sine bøger, er Theis Ørntoft. Det ses allerede i overskrifterne på de fire afsnit, som udgør Digte 2014 (2014).7 De er tituleret "Sort frekvens", "Bølge", "Elephantor" og "Arktisk kommando" og associerer hermed til apokalypsebevidsthed, oversvømmelsesscenarier, det posthumane og arktisk udstationering. Digtsamlingen præsenterer en dyster version af verden, hvor ting er underligt forskudt og ude af sine vante gænger. Det er tydeligt lige fra indledningsdigtet, der kan læses som et billede på det overgreb, mennesket har begået mod moderjord - "det man kaldte min mor" (Ørntoft, 5) - og hvor almindelige orienteringspunkter i form af tid, rum, personer og udsigelse er destabilisereret.

Videre igennem digtsamlingens forløb udfolder undergangsbevidstheden sig i billeder som "der vokser planter op gennem mine underboers halse / der vokser planter op gennem min etages gulve" (s. 15), "askelandskaber" (ibid.) og "befolkninger kvalt i forstenet honning" (ibid.). Også her opereres der på baggrund af klimaforandringerne med en postapokalyptisk verden og ses en radikal forandring af mennesket, der antager posthumane former. Det fremgår fx, idet en eftersøgt drabsmand er blevet fundet "inde i tv-stjernes barndomsminde" (s. 11), ligesom det ses i referencen til Elephantor fra serien Masters of the Universe og i en lang række andre sammenføringer af mennesker og dyr både konkret og sprogligt. Vi præsenteres for mennesker, der deler "hals med zebraens åndedræt" (s. 18), og vi hører om "Alger i luftrøret / i en blodforgiftnings skudår / bag skovene / hvor insekter og 
ansikter / fyger / vindstød gennem tomme byer / Saturn / Fornaxhoben / M63" (s. 43). I denne passage mikser insekterne sig også ortografisk med ansigterne, og derudover forbinder det postapokalyptiske scenarium sig med det kosmiske perspektiv, vi genkender fra sci-fi. Samme perspektiv anlægges, når jeget spørger: "De atomer jeg var som barn / er de stadig til stede på denne blå planet” (s. 22), eller nævner "smukke rumvæsener på gaden. / Springvand på pladserne, svedige håndflader på en klode / der ikke er anderledes dømt end altid" (s. 58).

I værkets sentidsskildringer er mennesket trængt i defensiven. Jeget, der er en i høj grad flertydig og flydende størrelse, fremstår som "en landingsbane for fjendtlige viljer" (s. 25), drømmer "at vi ikke længere fastholdt hinanden / i menneskelige former" (s. 15) og siger om sig selv: "Der er områder af mig / som ikke er menneskelige" (s. 38). Mennesket, som vi kender det, er ved at udvikle sig til noget nyt og fremmedartet, og i en tekst, der indledes "Verdenshistorien fortalt for mine efterkommere", betragter jeget da også i en tour de force menneskets udvikling fra stamceller, til det træder ud af sin fysiske form: "omkring år 3000 var mennesket ikke længere fysisk" (s. 53). Tilsvarende anvender det efterfølgende digt sci-fi-elementer i sin skildring af et opløst menneske: "og nu ligger jeg et sted blandt de atomer / og ser mine tænder svæve ud af munden / som en rumfærges besætningsmedlemmer" (s. 54).

Det er gennemgående, at Digte 2014 aktiverer sci-fi i kombination med klimakritiske aspekter og hermed forbinder sig med cli-fi. Samtidig skal det dog siges, at den kritik, værket italesætter gennem sin fremskrivning, forstærkning og underliggørelse af elementer, vi kender fra vores nuværende verden, ikke begrænser sig til et klimakritisk niveau, men i bred forstand udsætter den kapitalistiske vækstideologi for hug. Ligesom hos Skinnebach gælder det desuden, at bogen formmæssigt eftergør de nedbrydninger af hierarkier og dikotomiske strukturer, som destabiliseres på det tematiske niveau. Det sker bl.a., idet værket changerer imellem at kunne læses som enkelte digte og et langdigt eller en digtsuite, hvor tekstelementer udbygges, gentages og ændres igennem bogens forløb. Heller ikke her er det enkelte enkelt, men indskrevet i større og mere komplicerede sammenhænge. Det er en central erkendelse, som lægger op til, at værket kan ses som udtryk for det antropocænes mesh; det gensidigt påvirkende og uoverskuelige netværk af forbindelser, som alt levende og dødt indgår i (Morton, 29).

En tilsvarende, men ikke så radikalt fremstillet fornemmelse af at leve på kanten af en forestående klimakatastrofe formidles i Liv Sejrbo Lidegaards Fælleden (2015), der også flere steder trækker på repertoiret fra sci-fi og cli-fi. Det er tydeligst i samlingens sidste afsnit, der har overskriften "Det er sent", og som understreger det apokalyptiske perspektiv bl.a. gennem gentagelsen "det er sent, for sent" (Lidegaard, 47). I dette afsnit fremstilles et univers, hvor livet på jorden er under negativ forandring, og den velkendte verden går mod sit opgør. Afsnittet indledes ildevarslende med, at der kommer sort vand op af ristene, og gennemgående indtager vandelementer en fremtrædende plads. Det understreges, idet jeget skriver om at være "træt af oversvømmelsesscenarier" (s. 52), og vi flere steder hører, at hun får våde fødder. Vi præsenteres også for sammenblandinger af maritime og menneskelige elementer i passager som "spor / af sølinjer i din mund / og blågrønalger / i dit blå- 
grønne sind, ocean " (ibid.), og idet jeget "maver mig frem / blandt strålefinnede fisk" (s. 53). At klimakrisen i høj grad er en krise, som handler om global opvarmning og frygt for vandstandsstigninger, manifesteres her.

Et andet karakteristisk træk ved værkets apokalyptiske beskrivelser er, at de ofte forholder sig til et kosmisk perspektiv. Som det er typisk for sci-fi, reflekteres menneskets stedslige fundering ud fra en langt større skala end normalt. Det gælder fx udsagn som "jorden er en aktiv planet" (s. 50), "forstår sorte huller / som skæringspunkter med andre dimensioner" (s. 53) og "hver sfære har sin egen lyd / her befinder de fleste skyer sig" (s. 61). Digtsamlingen ender da også på én gang åbent og faretruende med teksten: "en ringer og siger / du skal altså lige komme udenfor på vandsiden / fordi solen er fuldstændig sindssyg / så jeg skynder mig derhen / på mine urolige menneskeben" (s. 69). Målt op mod universets voldsomme og uregerlige kræfter forekommer menneskets eksistens særdeles skrøbelig. Heller ikke hos Lidegaard er grunden sikker.

Kongenialt med Skinnebach er der endvidere en fornemmelse af, at mennesket "på kanten [...] så tæt ved afslutningen" (s. 66) må indstille sig på en anden måde at leve på. Der er en søgen efter nye fællesskaber, andre måder at forbinde sig med hinanden og forstå den indbyrdes afhængighed. I en af disse sammenhænge inkluderes der inventar fra sci-fi: "men et navnløst fællesskab / jorden? // men hvis der kommer aliens må de også komme med" (s. 33). Også Lidegaard flirter desuden med en naturmytologisk tilgang. Den viser sig i omtalen af "min nye shaman" (s. 49) og alfer (s. 59), ligesom der et sted står: "ud af sten og tåge vokser lav / ud af elledans bruskhat / ud af min hånd vokser en mælkebøtte / djævleurt" (s. 46). Beskrivelserne associerer til overnaturlige fænomener med tilknytning til ældre folketro - elementer, som mange fantasyværker i øvrigt også har taget til sig - og endnu engang oplever vi, at grænserne mellem menneskekroppen og den omgivne natur overskrides. Parallelt med hos Ørntoft gennembrydes kroppen af planter.

Med undtagelse af at der i Fælleden optræder fly, som cirkler faretruende rundt, er der ikke mange spor af sci-fi-genrens teknisk-videnskabelige inventar. Lidegaard udgår i højere grad fra et naturorienteret antropocænt udgangspunkt. Til gengæld er det tekniske perspektiv rigt repræsenteret hos den sidste danske eksponent for aktuel sci-fi- og cli-fi-poesi, som vi skal tager op her, nemlig Caspar Eric. Eric henter mange af sine referencer fra populærkulturens film og serier, og som en central figur står cyborgen. Det gælder ikke kun, når han i Nike (2015) henviser til "cyborgede superhelte" (Eric 2015, 22) og Bladerunners cyborg Rutger Hauer (s. 75), men også når han som forfatterportræt viser et billede af sig selv i kuvøse med undertitlen "Portræt af kunstneren som ung cyborg". Gentagne gange peges der på, hvordan grænserne mellem det menneskelige og ikke-menneskelige er udflydende, og dermed indskriver han sig i samme posthumane diskurs, som vi fandt hos Ørntoft.

Stadig er der dog også elementer i Nike, der binder an til klimakriseproblematikken og nærmer sig cli-fi. Eksempelvis kommenterer jeget kritisk på "kunstnervenner / der kun er optagede / af klimabevidsthed / som en strategi" (s. 31), ser "kollosale / mængder af postapokalyptisk Sci-Fi" (s. 44) på Netflix og noterer, at alle historier for tiden handler "om at vi er dømt til / at leve videre / efter at verden er gået under" (s. 45). Eric refererer desuden til "en selvdestruktiv dynamik / som vi 
kender fra det arktiske ishav" (s. 85), og som noget ikke tidligere set, indgår der en sex-scene, der blander klimakrise og sci-fi:

(6f jeg vil bare slikke dit krater

jeg vil sluge dine sorte huller

jeg vil mixe dig uendeligt

mange skinny bitches

med mit smeltevand

det er sådan jeg har det

her i de 11. timer

(s. 88)

I Avatar (2017), hvis titel og omslag har klare posthumane referencer, er der også en lang række elementer, der forbinder mennesker og maskiner og trækker på fremtidige forestillinger om det optimerede individ. Værkets centrale diskurs angår psykisk sygdom og selvmord, og herunder kritiserer det forestillingen om det afbalancerede menneske, der omtales som "en af vor tids mest absurde / og stigmatiserende mentalismer" (I,6). I forlængelse af dette fokus indeholder værket passager, der omhandler menneskets krop og sind som manipulerbart materiale. Der tales om "nye piller / der opgraderede mine mentale ID-kort" (I,9) og om at "genstarte mine lunger i en ny krop" (III,11), ligesom der er flere sammenligninger mellem mennesker og maskiner, fx "Jeg har det som en defekt maskine" (I,11), "jeg troede vi var en maskine / der umuligt kunne gå i stykker" (V,3), "vi er allerede robotter" (VIII,6) og der fantaseres om at

6 kunne / slette fra vores hukommelse / at vi havde set en menneskekrop [...] ligesom at slippe kravet / til alle vores robotter / om at mime et menneskeligt ansigt [...] men nu elsker jeg den ide / også at kunne findes / i en anderledes fysisk form / der kan lade os være koblet / til koncepter som tid og rum / på en anden måde / end hvis vi var bundet / til et præprogrammeret fartøj / der uundgåeligt kommer til at rådne (VIII, 10)

Mennesket anskues tydeligvis ud fra et teknificeret og instrumentaliseret perspektiv, og avataren bliver et symbol på muligheden for at transcendere sin egen fysiske og sjælelige form i en parallel verden. En verden, der ikke blot låner sit inventar fra computerspillet, men også fra sci-fi. I værket er der en gennemgående fornemmelse af, at virkeligheden er blevet indhentet af fremtiden. Bl.a. står der "men ingenting er længere fiktion / lige undtagen flyvende personbiler" (V,7), ligesom det i forlængelse af en omtale af Sigourney Weaver i Alien: Resurrection lyder: "engang var det en sci-fi dystopi / at Donald Trump skulle være præsident" (VII,9), og senere i samme afsnit: "verden er seriøst blevet sindssyg / verden er seriøst blevet Hunger Games" (VII,11). Selvom jeget også her gerne vil "bygge nye verdener" (VIII,11), er den nye verden i høj grad ankommet, og den er ikke til det bedre.

Mens vi i Nike kunne finde eksempler på brug af sci-fi i kombination med klimaspørgsmålet, trækker dette spor i Avatar i en anden retning, nemlig mod den del af det antropocæne, som danner parløb med det posthumane og viser, hvordan vante 
forestillinger om forholdet mellem det menneskelige og ikke-menneskelige er under ombrydning. Stadig har bøgerne dog en magtkritiksk og identitetspolitisk vinkling til fælles, som påpeger, hvordan mennesker udgrænses som afvigere, ligesom de begge mikser populærkulturelle, politiske og eksistentielle aspekter.

\section{Dislokeringer - eller sci-fi og cli-fi i et norsk og svensk perspektiv}

Refleksioner over forholdet mellem det menneskelige og ikke-menneskelige er også i centrum for norske Øyvind Rimbereids Solaris korrigert (2004), der er henlagt til år 2480 og er et gennemført eksempel på sci-fi-poesiens æstetisk innovative karakter, idet værket er skrevet på et særegent fremtidssprog, der kombinerer stavangerdialekt, skotsk, engelsk, nederlandsk, dansk og oldnordisk. Således er det både den verden, læseren træder ind i, og selve den sproglige form, hvori denne verden formidles, som er underliggjort. Langdigtet tager afsæt i et lyrisk jeg, som er operatør blandt robotter, der reparerer rør i havslammet uden for det såkaldte Stavgersand. Han viser sig at have en lille defekt i hjernen i form af "ein noko for staerk production / af eigne picts" (Rimbereid, 41). Med andre ord er han tænker og digter, og centralt i hans poetiske overvejelser står spørgsmålet om eksistensen og dens forskellige former.

Især gør jeget sig mange overvejelser over forholdet mellem robotter og mennesker. Han beskriver robotterne som lukkede, interne systemer uden selvrefleksion og interpersonel bevidsthed, men også som lykkelige og frie, når de har udført deres arbejde: "DA dei lucki er. / ONLI, dei veit det ne... / DEI veit ne wat dei haf i vorlden gerat, / fordi all onli intern i dei er. / MEN aig veit. / OG deirs hemlig luck i meg skinn!" (s. 18). I modsætning hertil har mennesker længsler og drømme (s. 19), og ikke kun står det lyriske jeg i et følelsesmæssigt komplekst forhold til kæresten Shiri; han er fysisk og psykisk forbundet til sine robotter og tolker dem ind i et større velsmurt fællesskab: "vidout grease / miner robots vul for lengst haf stifna... / GREASE er links total! [...] DU human, so greasen / ven du born!" (s. 25). Grænserne mellem det menneskelige og ikke-menneskelige er unægteligt noget flossede.

Gennem jegets fortælling erfarer vi, at der er planer om at omdøbe dets område, organic 14.6, til Solaris og flytte det permanent ned på havbunden, hvor det skal fungere som en parallel verden. "'DEN er den nyast og best mirror- / vorld, den nyast og most healthy af all!", siger lederen mrs. Chan (s. 35). I forbindelse hermed får jeget en sprøjte med "electric pico- / molekylen" (s. 38), som opgraderer hans syn til de nye forhold, og videre overvejer han, om han skal lade en duplikat skabe af sig, som vil kunne leve længe efter han selv er gået bort (s. 39f.). Ja, hvad sker der i det hele taget den dag, der ikke længere eksisterer mennesker, men kun maskiner? Jeget stiller dette og andre spørgsmål, men der gives ingen svar. Derimod ender langdigtet med, at jeget bliver kaldt ned på havets bund og ved indgangen til elevatoren møder en gammel mand, der som en anden Skt. Peter spørger, om han tror på Gud, hvilket jeget kun tøvende imødekommer, og dét “'AN ein GUD som mang feil ger..." (s. 44). Herefter åbner elevatoren sig, jeget går ind og farer nedad, mens hans krop svækkes, og grænserne til omverdenen opløses: "OG ven aig mot veggen vil taka, / det er som om aig ne kan touch, / ne kan touch ne / tings, vid infinit air 
millom miner fingren og elevator... / OG ne ryck i elevator, ne ryck i meg / ven elevator stops. / ONLI litl litl klick / ven kvar vegg umkring meg fell" (s.45). Det er en slutning, der lader stå åbent, hvilken verden jeget overgår til.

I Solaris korrigert er det ikke som i mange af de foregående værker katastrofe- og klimakrisediskursen, men derimod problematikken om det posthumane, der er i centrum. Vi befinder os ikke på cli-fi'ens domæne, men er i en mere klassisk afdeling af sci-fi, hvor vi entrerer et fremtidigt univers præget af en ny samfundsorden og domineret af teknologi. I pagt med centrale erkendelser i Antropocæn finder der en omkalfatring sted af mennesket, der allerede i vid udstrækning er erstattet af robotter og står over for at blive tranformeret til nye, posthumane former. Men selvom verden er blevet en ganske anden, synes det for jeget, der endnu har refleksiviteten i behold, at være nogle meget grundlæggende eksistentielle spørgsmål, der melder sig. Han viser sin menneskelighed ved netop at rejse spørgsmål om fx lykke, kærlighed, eksistens, fællesskab og tro. Hårdt presset af en ny teknologisk virkelighed træder menneskets særtræk klart frem, og som læser anspores man til at overveje, hvordan teknologien risikerer at udradere centrale humane værdier.

Mens det i Rimbereids langdigt gælder rejsen ned på havets bund, bevæger vi os hos en anden norsk sci-fi-poet, Maria Dorothea Schrattenholz, igen ud i det store verdensrum. Hendes debutdigtsamling Atlaspunkt (2015) er en kombination af en evolutionshistorie og en sci-fi-fremstilling. Bogen udgøres af fire afsnit: "Her", "Gjest", "Mars" og "Retur". Under disse overskrifter omhandler værket først menneskets oprindelse og liv i forhistorisk tid, derpå gengiver det en samtidshistorie med fokus på en mand, en kvinde og en lurende katastrofe, i den tredje del befinder vi os i en postapokalyptisk fremtid, hvor mennesket har bosat sig på Mars, for så i den sidste afdeling at følge en gruppe, der tager tilbage til Jorden. Hos Schrattenholz omkranser vi dermed tiden, lige fra mennesket rejser sig og for første gang bevæger sig rundt på Jordens overflade, til det på Mars lever i en anderledes let atmosfære, hvor den manglende tyngdekraft svækker dets evne til selvopretholdelse, og til det rejser tilbage og forsøger igen at lære at bære sin egen vægt.

Men selvom der således er en form for cirkelstruktur, som også markeres derved, at enkelte passager fra fremtiden kiler sig ind i fortidsafsnittet, er jegets finale erkendelse, at der ikke er nogen vej tilbage. Missionen om at generobre den tabte verden lykkes ikke: "det ble ikke som vi hadde tenkt / vi kan ikke snu oss tilbake / tiden går bare en vei" (s. 62). Ligesom hos Lidegaard lyder det: "det er for sent" (ibid.), og i samlingens slutning må jeget erkende sit nederlag: "Strukturene våre svaier, vil falle / alt vi ikke rakk å bygge / alt vi ikke fant / er ikke mitt / du vil ikke ha oss, jeg forstår / men jeg gjorde mitt beste, jeg mente det godt, det er sant / jeg gjorde som jeg ble fortalt" (s. 63). Nok bliver det aldrig entydigt beskrevet, hvad det er for en katastrofe, der har udløst den store brand og tvunget menneskene bort, alligevel fornemmer man, at der har med menneskets egen problematiske ageren at gøre (jf. s. 42), og at moderjord ikke vil tage det tilbage.

Det dystopiske perspektiv dominerer således også her, og samlingen ender med ordene: "den gylne byen sank / idet vi nådde frem / portene lukket seg så sakte / at vi rakk å stikke fingrene imellom" (s. 64). Med tydelig reference til Atlantis-myten nægtes menneskene adgang til fortiden, og den gyldne by forsvinder for øjnene af 
dem. Også i Schrattenholz' digtsamling taler dystopien højest. Værket flugter med cli-fi'ens betoning af den $\varnothing$ kologiske krises irreversibilitet og ansporer til refleksion over, hvordan en menneskehed, der ikke tager vare på sine omgivelser, risikerer for altid at blive afskåret fra sin historie.

Den sidste forfatter, der skal inddrages i denne behandling af aktuel sci-fi- og clifi-poesi, er svenske Johannes Heldén, der samtidig er den skandinaviske kunstner, der mest insisterende og fra flest forskellige tværæstetiske og tværmediale vinkler har beskæftiget sig med sci-fi. Hele hans produktion er ganske enkelt præget af denne optik, og det er da heller ikke for ingenting, at han har tatoveret Science Fiction på sin ene underarm. Mange steder i hans værker finder man desuden, at sci-fi og klimakrise går hånd i hånd, hvorfor han også er en central eksponent for cli-fi. Det er bl.a. tilfældet i digtsamlingen Science Fiction (2010), som skildrer et fremtidsscenarie under negativ forandring. Det menneskeliges domæne er på retur, og allerede på en af de første sider nævnes det, at "naturen tar över" (Heldén 2010, 9) og dét på højst foruroligende vis: "jag har alltid trott att naturen är välvillig men kanske är sanningen den / att den är likgiltig eller till och med fientligt inställd" (s. 44).

Et prægnant udtryk for de ændrede vilkår manifesterer sig i vejret, der er blevet voldsomt forværret. Vi hører om en flere år lang fimbullignende vinter, og inden for langdigtets egne tidslige rammer beskrives det gentagne gange, at det er uvejr med storm, hvirvelvinde og ikke mindst regn. Desuden har skoven tilranet sig selvstændig agens. Den omtales som en "superskog" (s. 56) og "har tagit över ljussignalerna nu" (s. 12). Med andre ord har naturen på forskellig vis invaderet eller overtrumfet den menneskeskabte virkelighed. Med værkets eget udtryk har verden været udsat for en 'naturbombe', og rollerne er blevet byttet om: "vi formade naturen se nu formar naturen oss" (s. 64).

Denne omvending af styrkeforholdet ses tydeligt, idet naturen trænger ind i menneskenes huse. Ikke bare den ydre, men også den indre virkelighed og endda vores fiktionsverdener genindtages af naturen. Allerede tidligt i langdigtet fortælles det, at bøgernes bogstaver ikke længere er stabile størrelser, men bliver selvlysende og forlader bogbindene (s. 13-14), og senere oplever vi, at bøgerne selv, der jo er lavet af papir fra skovens træer, føres tilbage til deres ophav:

Uf jag går genom korridorerna

och ser världarna växterna komma ut genom väggarna

bokhyllor böcker återgår

till trä till träd

i den mörka växtligheten små skärmar

ser miljoner universa

bildas och dö information som byter skepnad

det myllrar och väser tyst

det är som skogen alldeles innan gryningen

(s. 63)

Udviklingen viser sig at være en afvikling eller måske mere præcist: en tilbageerobring. 
De ændrede vilkår i den ydre verden følges hermed af ændringer i de indre og fiktive rum. Tanken fra Haraway og Clark om, at kunsten og herunder litteraturen må antage anderledes former, synes at blive taget bogstaveligt. Og ikke alene gælder det tematisk; æstetisk er Science Fiction også i opbrud. Det fremgår bl.a. af selve digtbilledets form, som slynger sig irregulært ned over papirsiderne og udnytter hele deres flade, ligesom det understreges i værkets andet og sidste afsnit, der er upagineret og hermed antyder, at vi har overskredet den almindelige tidslighed. Desuden er teksten på dette sted ekstremt springende, flersproglig og med referencer til andre værker inden for sci-fi og fantasy.

Heldéns nyeste digtsamling First Contact (2019) - hvis titel også henviser til et usædvanligt smukt bogobjekt fra 2011, hvor en bogs gennembrudte forside danner et vandspejl for vækst af små planter - leger tilsvarende med bogen som materiale og form. På forlagets hjemmeside præsenteres værket på følgende vis:

64 Ett kraschat, övervuxet rymdskepp på en okänd planet, i ett avlägset stjärnsystem. Den enda överlevande försöker förstå sin nya tillvaro. Med fragment från framtiden byggs ett arkiv upp över den förunderliga nya världen och resan dit, samt sorgen över en förlorad hemplanet och dess arter. Johannes Heldéns nya bok skildrar det okända och ifrågasätter det givna - vår plats i världsalltet. (https://www.albertbonniersforlag.se/bocker/217921/first-contact/)

Men selvom der således antydes et narrativ, er det værkets æstetisk sammensatte og fragmentariske karakter, der primært slår læseren. Idet vi åbner bogen, entrerer vi et fremmed univers, hvis indre omslag prydes af noget, der minder om to små skyer og har et citat af Ursula K. Le Guin som motto. Sci-fi'en kosmiske perspektiv er hermed anslået fra begyndelsen, og de første to tekster i det upaginerede værk cementerer genreforholdet: "rymdskeppet osynligt (i regndiset)" og "vi dödade andra varelser deras medvetanden". Vi befinder os altså endnu engang i et postapokalyptisk univers, hvor det antydes, at mennesket har andel i katastrofen. Videre igennem bogens forløb konfronteres vi med stort set alle sci-fi-genrens centrale karakteristika, hvortil hører beskrivelser af en udvidet tidslighed, ny teknologi, parallelle virkeligheder og anderledes eksistensformer, som overskrider mennesket: "en annan form av existens, ett icke-jag?"

Ligesom i Heldéns øvrige produktion finder fremskrivningen af den fremtidige verden desuden sted i samspil med en metafiktiv bevidsthed. I First Contact indgår der andre bøger med egne titelblade, nærmere bestemt "Fältguide till trädgården" og "Fältguide till framtida planet", der hypostaseres at være udkommet på forlaget Lost Coast Editions, som eksisterede fra 2021-2037, og hvis forskellige udgivelser der gøres rede for i en af bogens mange fodnoter. I den anden af bøgerne er der som en slags futuristisk parallel til Carl von Linnés tidlige botaniske systematiseringer en liste over nye former for organismer og vækster. Eksempelvis hører vi om "01. Sylvians skeppsmossa, blek, semi-intelligent organism. Frätande i kontakt med metall och syre, doftar såpa och skogsbrand” og "10. (Heldéns) eldfluga, interplanetär invasiv art. Sannolikt modifierad, mjöligen spontant evolverad. Empatisk strateg, kommunicerar via biolumniscens". Værket præsenterer os hermed ikke alene for 
nye eksistensformer, men også anderledes måder at kommunikere på. Spørgsmålet om nye virkeligheder hører intimt sammen med opkomsten af nye sprog, hvilket understreges i udsagn som "Okända alfabet på displayer" og "fiktiva utomjordiska alfabet". Med dette værk får vi et sidste eksempel på, hvordan den skandinaviske sci-fi-poesi ikke alene indholdsmæssigt fremstiller nye verdener, men også æstetisk er særdeles innovativ.

\section{Exit}

Med fokus på skandinavisk poesi har denne artikel diskuteret, hvordan sci-fi tilbyder en oplagt ramme for forfattere, som er optaget af samtidens markante sociale, teknologiske og miljømæssige problematikker, idet genren lægger op til refleksion over, hvor udviklingen fører os hen. Den skandinaviske sci-fi-poesi er ikke tidligere blevet behandlet som et samlet fænomen, og som fundament for dette projekt har jeg derfor fundet det vigtigt først at introducere til fænomenet sci-fi-poesi og henvise til nogle af den skandinaviske sci-fi-poesis historiske rødder. Siden er artiklens hovedvægt blevet lagt på en analyse af aktuel skandinavisk sci-fi-poesi og herunder særligt den del, som forholder sig til Antropocæn og klimakrise. Netop denne vinkling af sci-fi dominerer i disse år, hvilket skyldes en øget bevidsthed om, at mennesket har grebet uopretteligt ind i naturgrundlaget, og at klimakrisen sætter en fundamentalt forandret dagsorden for vores fremtid. Cli-fi, som er betegnelsen for en litteratur, der fremskriver billeder af, hvordan det er at leve i en klimaforandret verden, er blevet en af de dominerende former for sci-fi, og som jeg argumenterer for, er der ingen grund til at reservere begrebet til prosafiktion og film. Der udkommer tilsvarende mange lyriske værker, der oplagt kan reflekteres ud fra denne betegnelse.

Ved at rette opmærksomheden mod syv danske, norske og svenske forfatteres poetiske værker har jeg ønsket at give et bredspektret indblik i, hvordan skandinaviske lyrikere har indoptaget sci-fi i deres værker, og hvordan det antropocæne og klimakrisen også her influerer afgørende på, hvordan det sker. Klimakrisen fremstår aktuelt som en af de mest faretruende katastrofer og sætter en dyster dagsorden, som påvirker forfatternes diagnosticering af fremtidsperspektiverne. Foruroligende vejrfænomener, smeltende is og stigende vandstande opleves hos fx Skinnebach, Lidegaard og Heldén. Som både Stableford og Auklend fremhæver, er genrens utopiske elementer generelt blevet trængt i baggrunden for dystopien. Nok er de menneskelige værdier ikke alle steder knægtet, og nok er der stadig drømme og længsler - ikke mindst efter nye fællesskaber - men i langt de fleste værker er håbet kun spinkelt. Der synes ikke at være nogen vej tilbage; derimod skriver mange af digtsamlingerne sig frem mod undergangsscenarier. Vi befinder os i en tærskelsituation og ved overgangen til det ukendte, hvilket er særligt prægnant i de måder, som Lidegaard, Rimbereid, Schrattenholz og Heldéns bøger ender på.

I en del tilfælde rækker værkernes kritik desuden videre mod en generel samfundskritik og herunder en kritik af den kapitalistiske vækstideologi. En vækstideologi, der ikke kun - som Skinnebach betoner - har affødt en manglende vilje til at tage hånd om klimaproblemerne, men som også har ført til et stadigt 
mere effektivt og gennemteknologiseret samfund, hvor der ikke altid er lige megen plads til menneskelig forskellighed og sårbarhed. Det oplever vi især i posthumane menneske-maskine-interaktioner hos Ørntoft, Eric og Rimbereid. Endvidere peger dette forhold på, at der inden for denne gren af litteraturen ofte er flere forskellige diskurser i spil, og de værker, vi har været omkring, relaterer da heller ikke alene til sci-fi og cli-fi, men kan også oplagt reflekteres ud fra andre litterære kategorier som det antropocæne, posthumane, dystopiske og klimakritiske, ligesom værkerne overordnet støtter op om mit indledende synspunkt om, at poesien i disse år viser sig tydeligt engageret i de problematikker, som præger den samfundsmæssige dagsorden.

Uanset om værkerne indskriver sig i den klimakritiske diskurs eller fremviser mere teknisk-videnskabeligt vinklede fremtidsforestillinger, er det et gennemgående træk, at de markerer et opgør med en realistisk æstetik og illustrerer et behov for også på det æstetiske niveau at finde udtryksmåder, der matcher de erfaringer, som knytter sig til den antropocæne tidsalder. Som Collings har gjort opmærksom på, er sci-fi-poesi en i høj grad eksperimenterende genre, og de værker, vi har beskæftiget os med, er da også alt andet end udtryk for trivial populærlitteratur. De er kendetegnet ikke blot af et kognitivt, men også et æstetisk novum og stiller i mange tilfælde store krav til læserens såvel imaginative kraft som evne til at forstå fx særegne sprogblandinger, kompleks metaforik, opbrudt syntaks og skiftende udsigelsespositioner. Særligt udfordrende er Skinnebach, Rimbereid, Ørntoft og Heldéns poetiske stil, mens Lidegaard, Schrattenholz og Eric er lettere at følge i hvert fald på det syntaktiske plan. Alle er de imidlertid engagerede forfattere, hvis værker viser, hvordan poesien ved at opsøge nye og anderledes måder at formulere og positionere sig på også kan lægge op til anderledes tænke- og handlemåder. Det er en vigtig funktion både for samtidens og fremtidens litteratur.

\section{Noter}

I I denne artikel omtaler jeg gennemgående sci-fi som en genre. Det gør jeg af den enkle grund, at det oftest er det, man gør, og at jeg ikke er inde i et genreteoretisk ærinde. Imidlertid synes jeg, at der er god mening i Søren Baggesens forslag om at betragte sci-fi som en modus, dvs. som en bestemt måde at stemme forskellige former for litteratur på. Baggesen skriver: "Når jeg foreslår begrebet modus er det udelukkende for at sige, at en fortælling må have så meget af et bestemt udseende for at kunne kaldes science fiction, at det også 'stemmer' fortællingen på en bestemt måde. Det bestemte udseende er det som er angivet i etikettens bastardbegreb 'science fiction': det drejer sig om 'fiktioner' som på den ene eller anden måde bruger 'videnskaben' for at blive den slags fiktioner, de er" (Baggesen, 18). En fordel ved modusbegrebet er desuden, at det gør det lettere at anvende sci-fi som en betegnelse for tekster, der på tværs af genreskellene prosa, drama og lyrik kan have fælles karaktertræk, der definerer dem som netop sci-fi.

2 Et tilsvarende synspunkt om den miskrediterede genre har forfatteren Kristian Leth gjort sig til talsmand for, hvilket imidlertid fik kritikeren Anna Raaby Ravn til at respondere, at han måtte have sovet i timen. Under overskriften "Brandvarm sci-fi" i Information 20. maj 2017 skrev hun: "Kritikken havde muligvis ramt plet for et årti eller to siden, hvor fantasy og sf-litteratur ofte blev beskyldt for at være mindre seriøs litteratur, men i dag er sf langtfra 'underlødig' i det, jeg tror, 
Leth vil betegne som 'det litterære Danmark"'. Denne påstand underbyggede hun ved at nævne, at forfatterskolen har udbudt forløb om sci-fi-litteratur, ligesom hun pegede på mange sci-fiforfattere, som læses og anerkendes af det litterære establishment. Hertil kan tilføjes, at Forlaget Gladiator i det fjerde nummer af litteraturbladet Texas Longhorn har haft temaet "Sf \& Horror", ligesom artikler af bl.a. Gregers Andersen og Jens Kramhøj Flinker har givet opmærksomhed til særligt den skandinaviske cli-fi. På universiteternes litteraturstudier skrives der også i disse år flere opgaver om emnet, og her er Maria Olofson Danborgs speciale Cyborgs og tidsrejser-science fiction i Caspar Eric og Theis Ørntofts lyrik et eksempel på, at opmærksomheden også er vakt omkring genrens lyriske potentiale.

3 Se kapitlet "De danske science fiction-magasiner" i Dalgaard 2015.

4 Dalgaard forbigår helt den poetiske genre i Vinkler på dansk science fiction. Han anerkender, at sci-fi kan findes inden for alle genrer og anfører også, at der principielt vil kunne skrives sci-fisonetter. Til trods for hans store kendskab til og imponerende overblik over sci-fi, er det dog tydeligt, at han ikke har interesseret sig for genrens poetiske varianter. Sådanne sonetter er nemlig allerede skrevet af Klaus Høeck i Projekt Perseus' afsnit "Hyperion. Interplanetariske sonetter".

5 Det dystopiske og apokalyptiske perspektiv i samtidens litteratur er også blevet behandlet i andre sammenhænge og herunder i tidsskriftet Spring nr. 38, som har titlen "Sæt verden ikke er til". Endvidere har Martin Gregersen og Tobias Skiveren udgivet bogen Den materielle drejning (2016), der i et kapitel om “Teknologi og litteratur” behandler beslægtede problematikker med reference til posthumanisme og dystopi, ligesom de berører spørgsmålet om sci-fi, uden at dette er kapitlets primære fokus.

6 Maria Olofson Danborg kommenterer på denne uforenelighed i sit speciale om sci-fi hos Eric og Ørntoft og anfører: "Dalgaard skriver, at 'Lyrikken er af indbyggede årsager (dens afhængighed af metaforen) ikke forenelig med science fiction på samme måde som prosaen.' [...] Denne afhængighed af metaforen, og det faktum, at poesien ikke abonnerer på det virkelighedsbegreb, som novummet baserer sig på, gør, at flere teoretikere forholder sig skeptisk til SF-lyrik. Dette bemærker teoretikeren Seo-Young Chu også i Do metaphors dream of literal sleep? (2010), hvor hun opremser over 20 vigtige teoretiske eller encyklopædiske værker om SF, som fuldstændig ignorerer forholdet mellem SF og lyrik" (Danborg 2018, 10).

7 Jeg har tidligere skrevet om denne digtsamling i andre sammenhænge, hvor jeg bl.a. har fokuseret på værkets relation til det antropocæne og posthumane, ligesom jeg har diskuteret dets karakter af langdigt. Værket blev hurtigt kanoniseret og har allerede en rig receptionshistorie. Se fx. min bog Ny nordisk lyrik $i$ det 21. århundrede (2016) og artiklen "Antropocæn poesi: Et spor i ny skandinavisk digtning" (2017), hvor jeg også behandler flere af de andre digtsamlinger, jeg kommer ind på i denne artikel.

\section{Litteratur}

Auklend, Morten (2010): "EIN systm total"? Utopier og dystopier i norsk etterkrigslitteratur. Bergen: Universitetet i Bergen.

Baggesen, Søren (1993): Natur/videnskab/fortælling. Om science fiction som civilisationskritik. Odense: Odense Universitetsforlag.

Clark, Timothy (2013): "Nature, Post Nature". I Louise Westling (red): The Cambridge Introduction to Literature and the Environment. Cambridge: Cambridge University Press, s. 75-89. 
http://www.starshineandshadows.com/essays/2004-03-29.html.

Dalgaard, Niels (2015): Vinkler på dansk science fiction. Kbh.: Science Fiction Cirklen.

Danborg, Maria Olofson (2018): Cyborgs og tidsrejser - science fiction i Caspar Eric og Theis Ørntofts lyrik. Københavns Universitet, upubliceret speciale.

Eric, Caspar (2015): Nike. Kbh.: Gyldendal.

Eric, Caspar (2017): Avatar. Kbh.: Gyldendal.

Flinker, Jens Kramshøj (2018): “Den skandinaviske cli-fi. En ny genre i Antropocæn?”. Spring nr. 42, s. 41-66.

Haraway, Donna (2014): "Anthropocene, Capitalocene, Chthulucene: Staying With the Trouble". Findes på http://opentranscripts.org/transcript/anthropocene-capitalocene-chthulucene/.

Gregersen, Martin og Tobias Skiveren (2016): Den materielle drejning. Natur, teknologi og krop i (nyere) dansk litteratur, Odense: Syddansk Universitetsforlag.

Heldén, Johannes (2010): Science Fiction. Stockholm: Albert Bonniers Forlag.

Heldén, Johannes (2019): First Contact. Stockholm: Albert Bonniers Forlag.

Lidegaard, Liv Sejrbo (2015): Fælleden. Kbh.: Gyldendal.

Morton, Timothy (2010): The Ecological Thought. Cambridge: Harvard University Press.

Ravn, Anna Raaby (2017): "Brandvarm sci-fi". Information 20.5. Findes på https://www.information.dk/kultur/2017/05/brandvarm-sci-fi.

Rimbereid, Øyvind (2005): Seine topografier. Trådreiser. Solaris korrigert. Oslo: Gyldendal.

Schrattenholz, Maria Dorothea (2015): Atlaspunkt. Oslo: Forlaget oktober.

Seed, David (2005): "Introduction: Approching Science Fiction". I A Companion to Science Fiction. Oxford: Blackwell Publishing, s. 1-7.

Skinnebach, Lars (2011): Øvelser og rituelle tekster. Kbh.: After Hand.

Skinnebach, Lars (2018): TEOTWAWKI. Kbh: Gyldendal.

Stableford, Brian (2005): "Science Fiction and Ecology". I David Seed (red.): A Companion to Science Fiction. Oxford: Blackwell Publishing, s. 127-141.

Ørntoft, Theis (2014): Digte 2014. Kbh.: Gyldendal.

\section{Hjemmesider}

https://www.albertbonniersforlag.se/bocker/217921/first-contact/

https://www.sfpoetry.com/ 